\title{
Devosia soli sp. nov., isolated from greenhouse soil in Korea
}

\author{
Seung-Hee Yoo, ${ }^{1}$ Hang-Yeon Weon, ${ }^{2}$ Byung-Yong Kim, ${ }^{1}$ \\ Seung-Beom Hong, ${ }^{1}$ Soon-Wo Kwon, ${ }^{1}$ Yang-Hee Cho, ${ }^{1}$ Seung-Joo Go ${ }^{1}$ \\ and Erko Stackebrandt ${ }^{3}$
}

Correspondence
Soon-Wo Kwon
swkwon@rda.go.kr

\author{
${ }^{1}$ Korean Agricultural Culture Collection (KACC), Genetic Resources Division, National Institute \\ of Agricultural Biotechnology, Rural Development Administration, Suwon 441-707, Korea \\ ${ }^{2}$ Applied Microbiology Division, National Institute of Agricultural Science and Technology, Rural \\ Development Administration, Suwon 441-707, Korea \\ ${ }^{3}$ Deutsche Sammlung von Mikroorganismen und Zellkulturen $\mathrm{GmbH}$, Mascheroder Weg $1 \mathrm{~b}$, \\ D-38124 Braunschweig, Germany
}

\begin{abstract}
A Gram-negative, obligately aerobic, rod-shaped bacterium was isolated from greenhouse soil used to cultivate lettuce. The strain, $\mathrm{GH} 2-10^{\top}$, was characterized on the basis of phenotypic and genotypic data. 16S rRNA gene sequence analysis revealed that the isolate belonged to the genus Devosia, with highest sequence similarity $(98.5 \%)$ to Devosia riboflavina IFO $13584^{\top}$. Sequence similarities with other strains tested were below $97 \cdot 0 \%$. Strain $\mathrm{GH} 2-10^{\top}$ had $\mathrm{Q}-10$ as the predominant ubiquinone and $\mathrm{C}_{18: 1} \omega 7 c$ and $\mathrm{C}_{16: 0}$ as the major fatty acids. The $\mathrm{G}+\mathrm{C}$ content of the genomic DNA was $59.5 \mathrm{~mol} \%$. The results of DNA-DNA hybridization experiments $(47 \%$ relatedness between $D$. riboflavina DSM $7230^{\top}$ and strain $\mathrm{GH} 2-10^{\top}$ ) and physiological and biochemical tests suggested that strain $\mathrm{GH} 2-10^{\top}$ represents a novel species of the genus Devosia, for which the name Devosia soli sp. nov. is proposed. The type strain is $\mathrm{GH} 2-10^{\top}$ (= KACC $11509^{\top}=$ DSM $17780^{\top}$ ).
\end{abstract}

Nakagawa et al. (1996) erected the genus Devosia with the transfer of 'Pseudomonas riboflavina' (Foster, 1944) to Devosia riboflavina. Since then, Devosia neptuniae (Rivas et al., 2003), 'Candidatus Devosia euplotis' (Vannini et al., 2004) and Devosia limi (Vanparys et al., 2005) have been described within the genus.

In the present study, a soil sample was collected from a greenhouse planted with lettuce (Lactuca sativa L.) in Daejeon City, Korea. The soil sample was diluted and spread on R2A medium (Reasoner \& Geldreich, 1985). Strain GH2$10^{\mathrm{T}}$ was isolated after incubation for 5 days at $28^{\circ} \mathrm{C}$.

The morphological, physiological and biochemical characteristics of strain $\mathrm{GH} 2-10^{\mathrm{T}}$ were tested using routine cultivation on R2A medium at $28{ }^{\circ} \mathrm{C}$. Gram staining, presence of oxidase and catalase and hydrolysis of agar, casein, DNA, gelatin and starch were determined as described by Smibert \& Krieg (1994). Motility testing was performed on one-tenth strength R2A broth supplemented with $0 \cdot 2 \%$ agar. Growth was assessed at 5, 10, 20, 25, 30, 37, 40 and $45^{\circ} \mathrm{C}$, at $\mathrm{pH} 4,5,6,7,8,9$ and 10 and at $0,1,3,5$ and $7 \% \mathrm{NaCl}$. Anaerobic growth was checked by using a BBL

The GenBank/EMBL/DDBJ accession number for the $16 \mathrm{~S}$ rRNA gene sequence of strain $\mathrm{GH} 2-10^{\top}$ is DQ303125. anaerobic jar (Becton Dickinson), with incubation for up to 21 days. Carboxymethylcellulose (CM-cellulose; Sigma) $(0 \cdot 1 \%, \mathrm{w} / \mathrm{v})$ and tyrosine $(0 \cdot 5 \%, \mathrm{w} / \mathrm{v})$ were also used. Strain $\mathrm{GH} 2-10^{\mathrm{T}}$ was additionally characterized by using the whole test spectra of the API 20NE, API 50CH and API ZYM (bioMérieux) systems according to the manufacturer's instructions. For tests of antimicrobial susceptibility, discs containing the following antibiotics were used: amikacin $(30 \mu \mathrm{g})$, ampicillin $(10 \mu \mathrm{g})$, chloramphenicol $(30 \mu \mathrm{g})$, ciprofloxacin $(5 \mu \mathrm{g})$, gentamicin $(10 \mu \mathrm{g})$, kanamycin $(30 \mu \mathrm{g})$, methicillin $(5 \mu \mathrm{g})$, polymyxin B (300 U), rifampicin $(5 \mu \mathrm{g})$, tetracycline $(30 \mu \mathrm{g})$ and vancomycin $(30 \mu \mathrm{g})$.

The strain grew rapidly (2 days) on R2A and nutrient agar (NA; Difco) and rather slowly (5 days) on trypticase soy agar (TSA; Difco) and did not grow on MacConkey agar (Difco). The $\mathrm{pH}, \mathrm{NaCl}$ concentration and temperature

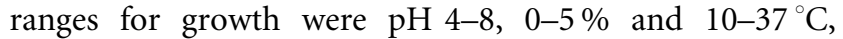
respectively. Strain $\mathrm{GH} 2-10^{\mathrm{T}}$ was catalase-positive and oxidase-negative. The isolate hydrolysed starch, CMcellulose and urea, but not casein, DNA, gelatin or tyrosine. Hydrolysis of urea was negative after incubation for 2 days, but positive after 7 days. According to the API 20NE test strips, strain $\mathrm{GH} 2-10^{\mathrm{T}}$ did not assimilate any substrates (up to 7 days incubation). API $50 \mathrm{CH}$ strips did not give reproducible results even with prolonged incubation (up to 
Table 1. Differential physiological characteristics of strain $\mathrm{GH} 2-10^{\top}$ and the type strains of recognized members of the genus Devosia

Strains: 1, strain GH2-10 ${ }^{\mathrm{T}}$; 2, D. riboflavina DSM $7230^{\mathrm{T}} ; 3$, D. neptuniae LMG $21357^{\mathrm{T}}$; 4, D. limi LMG $22951^{\mathrm{T}}$. All strains were positive for catalase and negative for hydrolysis of CM-cellulose. In the API 20NE and API ZYM test strips, all strains were positive for aesculin hydrolysis, alkaline and acid phosphatase, leucine arylamidase, naphthol-AS-BI-phosphohydrolase, $\beta$-galactosidase, $\beta$-glucosidase and $N$-acetyl- $\beta$ glucosaminidase. All strains were negative for lipase (C14), cystine arylamidase, $\alpha$-chymotrypsin, $\beta$-glucuronidase, nitrate reduction, indole production, glucose fermentation, arginine dihydrolase and gelatinase. Data are from Vanparys et al. (2005) and this study. +, Positive; $(+)$, weakly positive; - , negative.

\begin{tabular}{|c|c|c|c|c|}
\hline Characteristic & 1 & 2 & 3 & 4 \\
\hline \multicolumn{5}{|l|}{ Hydrolysis of: } \\
\hline Casein & - & - & + & - \\
\hline Starch & + & + & - & - \\
\hline Tyrosine & - & - & - & + \\
\hline Oxidase & - & + & + & + \\
\hline \multicolumn{5}{|l|}{ Enzyme activities: } \\
\hline Esterase lipase (C4 and C8) & + & + & - & $(+)$ \\
\hline$\alpha$-Galactosidase, $\alpha$-fucosidase & - & + & + & - \\
\hline$\alpha$-Glucosidase & + & - & - & - \\
\hline$\alpha$-Mannosidase & + & + & + & - \\
\hline \multicolumn{5}{|l|}{ Assimilation of: } \\
\hline Glucose, arabinose, mannose, mannitol, maltose & - & + & + & - \\
\hline$N$-Acetylglucosamine & - & + & - & - \\
\hline Presence of nifH and nodC genes & - & - & + & - \\
\hline DNA G $+\mathrm{C}$ content $(\mathrm{mol} \%)$ & $59 \cdot 5$ & $61 \cdot 4$ & $62 \cdot 0$ & $61 \cdot 9$ \\
\hline
\end{tabular}

7 days). Strain GH2-10 $0^{\mathrm{T}}$ was sensitive to all the antibiotics tested except gentamicin and polymyxin B. Details of the physiological and biochemical properties of strain GH2-10 ${ }^{\mathrm{T}}$ are given in Table 1 and in the species description below.

The DNA G + C content of the isolate was determined with an HPLC method as described by Mesbah et al. (1989) by using a reversed-phase column (Supelcosil LC-18-S; Supelco). The cellular fatty acid profile was determined by using the standard protocol of the Microbial Identification System (MIDI; Microbial ID) after cells were grown on TSA for $48 \mathrm{~h}$ at $28{ }^{\circ} \mathrm{C}$. Isoprenoid quinones were analysed by HPLC as described by Groth et al. (1996). The DNA G + C content was $59.5 \mathrm{~mol} \%$. The predominant fatty acids of strain $\mathrm{GH} 2-10^{\mathrm{T}}$ were $\mathrm{C}_{18: 1} \omega 7 c(67 \cdot 2 \%), \mathrm{C}_{16: 0}(12 \cdot 7 \%), 11$ methyl $\mathrm{C}_{18: 1} \omega 7 c(5 \cdot 8 \%)$ and $\mathrm{C}_{18: 0} 3-\mathrm{OH}(5 \cdot 2 \%)$ (Table 2$)$. The major respiratory lipoquinone of strain $\mathrm{GH} 2-10^{\mathrm{T}}$ was ubiquinone 10 (Q-10).

The 16S rRNA gene sequence of strain GH2-10 $0^{\mathrm{T}}$ was amplified by PCR using conserved primers, as described by Kwon et al. (2003), and direct sequencing (Hiraishi, 1992). Multiple alignments with sequences of isolate GH2-10 ${ }^{\mathrm{T}}$ and those of members of the genus Devosia and Rhizobium leguminosarum USDA $2370^{\mathrm{T}}$ were carried out with the CLUSTAL W program (Thompson et al., 1994). A phylogenetic tree was reconstructed using the neighbour-joining method of Saitou \& Nei (1987) on MEGA version 2.1 (Kumar et al., 2001) (Fig. 1). The stability of relationships was assessed by performing bootstrap analyses of the neighbourjoining data based on 1000 resamplings.
The nearly complete $16 \mathrm{~S}$ rRNA gene sequence (1417 bp) of strain $\mathrm{GH} 2-10^{\mathrm{T}}$ was subjected to comparative analysis. Phylogenetically, strain $\mathrm{GH} 2-10^{\mathrm{T}}$ was most closely related to D. riboflavina IFO $13584^{\mathrm{T}}$, with a sequence similarity of $98.5 \%$. The sequences of other Devosia strains were shown to have similarities of $<97 \%$ to strain $\mathrm{GH} 2-10^{\mathrm{T}}$.

Levels of DNA-DNA hybridization were determined based on a membrane filter technique using a DIG High Prime

Table 2. Cellular fatty acid profiles of strain $\mathrm{GH} 2-10^{\top}$ and the type strains of recognized members of the genus Devosia

Strains: 1, strain $\mathrm{GH} 2-10^{\mathrm{T}} ; 2$, D. riboflavina DSM $7230^{\mathrm{T}} ; 3$, D. neptuniae LMG $21357^{\mathrm{T}}$; 4, D. limi LMG $22951^{\mathrm{T}}$. Only fatty acids that represent more than $1 \%$ of the total are included.

\begin{tabular}{|lcccc|}
\hline Fatty acid & $\mathbf{1}$ & $\mathbf{2}$ & $\mathbf{3}$ & $\mathbf{4}$ \\
\hline $\mathrm{C}_{10: 0} 3-\mathrm{OH}$ & $3 \cdot 5$ & $2 \cdot 7$ & - & $1 \cdot 3$ \\
$\mathrm{C}_{16: 0}$ & $12 \cdot 7$ & $14 \cdot 7$ & $19 \cdot 0$ & $9 \cdot 7$ \\
$\mathrm{C}_{18: 1} \omega 7 c$ & $67 \cdot 2$ & $68 \cdot 3$ & $43 \cdot 9$ & $49 \cdot 2$ \\
$\mathrm{C}_{18: 0}$ & $3 \cdot 0$ & $2 \cdot 6$ & $5 \cdot 2$ & $10 \cdot 0$ \\
$11-\mathrm{Methyl} \mathrm{C}_{18: 1} \omega 7 c$ & $5 \cdot 8$ & $6 \cdot 8$ & $18 \cdot 8$ & $19 \cdot 4$ \\
$\mathrm{C}_{18: 0} 3-\mathrm{OH}$ & $5 \cdot 2$ & - & $2 \cdot 0$ & $2 \cdot 4$ \\
Cyclo-C $_{19: 0} \omega 8 c$ & - & - & $1 \cdot 6$ & - \\
Summed feature 3* & $2 \cdot 8$ & $3 \cdot 0$ & $4 \cdot 7$ & $2 \cdot 8$ \\
Unknown $14 \cdot 959$ & - & - & $2 \cdot 4$ & $2 \cdot 0$ \\
\hline
\end{tabular}

${ }^{*}$ Summed feature 3 comprises $\mathrm{C}_{16: 1} \omega 7 c$ and/or iso- $\mathrm{C}_{15: 0} 2-\mathrm{OH}$. 


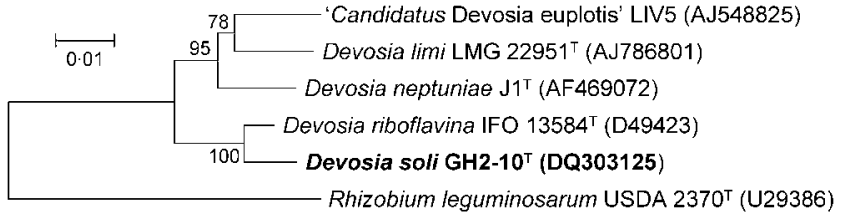

Fig. 1. Neighbour-joining phylogenetic tree, based on $16 \mathrm{~S}$ rRNA gene sequences, showing the position of strain $\mathrm{GH} 2-$ $10^{\top}$. Bootstrap values are shown as percentages of 1000 replicates. GenBank accession numbers are given in parentheses. Bar, 1 substitution per 100 nucleotides.

DNA labelling and detection starter kit II (Roche Molecular Biochemicals) (Kwon et al., 2003). Relatedness between strain $\mathrm{GH} 2-10^{\mathrm{T}}$ and D. riboflavina DSM $7230^{\mathrm{T}}$ was $47 \%$. This value was lower than the $70 \%$ value considered to be the threshold for the delineation of genomic species (Stackebrandt \& Goebel, 1994), and clearly indicated that strain $\mathrm{GH} 2-10^{\mathrm{T}}$ represented a different species from $D$. riboflavina.

To test the presence of the nitrogen-fixing genes nodC and nifH, PCR was conducted according to the method of Rivas et al. (2002). The primer pairs for the amplification of the nodC and nifH genes were nodCF $\left(5^{\prime}\right.$ AYGTHGTYGAYGACGGTTC- $\left.3^{\prime}\right)$ and nodCI (5'CGYGACAGCCANTCKCTATTG-3') (Laguerre et al., 2001), and 5'-GTCTCCTATGACGTGCTCGG-3' and 5'GCTTCCATGGTGATCGGGGT-3' (Rivas et al., 2002), respectively. Whereas $R$. leguminosarum LMG $14904^{\mathrm{T}}$, Ensifer fredii LMG $6217^{\mathrm{T}}$, Mesorhizobium loti LMG $6125^{\mathrm{T}}$ and Bradyrhizobium japonicum LMG $6138^{\mathrm{T}}$ formed PCR fragments of the expected size, strain $\mathrm{GH} 2-10^{\mathrm{T}}$ and $D$. riboflavina DSM $7230^{\mathrm{T}}$ did not.

On the basis of its phenotypic characteristics, which differ from those of recognized species of the genus Devosia, 16S rRNA gene sequence analysis and levels of DNA-DNA relatedness, strain $\mathrm{GH} 2-10^{\mathrm{T}}$ is considered to represent a novel species of the genus Devosia, for which we propose the name Devosia soli sp. nov.

\section{Emended description of the genus Devosia Nakagawa et al. 1996}

The description is as given by Rivas et al. (2003), with the following amendments. Oxidase-positive or oxidasenegative. The $\mathrm{G}+\mathrm{C}$ content of the DNA is $59-63 \mathrm{~mol} \%$.

\section{Description of Devosia soli sp. nov.}

Devosia soli (so'li. L. gen. n. soli of soil).

Cells are Gram-negative, obligately aerobic, nonspore-forming and rod-shaped (about $0 \cdot 4-0 \cdot 6 \mu \mathrm{m}$ wide and $1 \cdot 5-3.5 \mu \mathrm{m}$ long). Colonies are light beige and round with clear margins after 2 days on R2A medium. Tolerates up to $5 \% \mathrm{NaCl}$ and grows at temperatures between 10 and $37^{\circ} \mathrm{C}$. Growth occurs at initial $\mathrm{pH}$ values between 4 and 8 . Catalase-positive and oxidase-negative. Hydrolyses starch, CM-cellulose and urea, but not casein, DNA, gelatin or tyrosine. Contains $\mathrm{C}_{18: 1} \omega 7 c(67 \cdot 2 \%), \mathrm{C}_{16: 0}(12 \cdot 7 \%), 11-$ methyl $\mathrm{C}_{18: 1} \omega 7 c(5 \cdot 8 \%)$ and $\mathrm{C}_{18: 0} 3-\mathrm{OH}(5 \cdot 2 \%)$ as major fatty acids and Q-10 as the predominant ubiquinone. The DNA G $+\mathrm{C}$ content is $59 \cdot 5 \mathrm{~mol} \%$. The closest relative on the basis of $16 \mathrm{~S}$ rRNA gene sequence similarity is Devosia riboflavina.

The type strain, GH2-10 ${ }^{\mathrm{T}} \quad\left(=\mathrm{KACC} \quad 11509^{\mathrm{T}}=\mathrm{DSM}\right.$ $\left.17780^{\mathrm{T}}\right)$, was isolated from greenhouse soil planted with lettuce (Lactuca sativa L.) in Daejeon City, Korea.

\section{Acknowledgements}

This work was supported by a grant (Code \#20050401034815) from the BioGreen 21 Program, Rural Development Administration, Republic of Korea.

\section{References}

Foster, J. W. (1944). Microbiological aspects of riboflavin. I. Introduction. II. Bacterial oxidation of riboflavin to lumochrome. J Bacteriol 47, 27-41.

Groth, I., Schumann, P., Weiss, N., Martin, K. \& Rainey, F. A. (1996). Agrococcus jenensis gen. nov., sp. nov., a new genus of actinomycetes with diaminobutyric acid in the cell wall. Int J Syst Bacteriol 46, 234-239.

Hiraishi, A. (1992). Direct automated sequencing of $16 \mathrm{~S}$ rDNA amplified by polymerase chain reaction from bacterial cultures without DNA purification. Lett Appl Microbiol 15, 210-213.

Kumar, S., Tamura, K., Jakobsen, I.-B. \& Nei, M. (2001). MEGA2: molecular evolutionary genetics analysis software. Bioinformatics 17, 1244-1245.

Kwon, S. W., Kim, J. S., Park, I. C., Yoon, S. H., Park, D. H., Lim, C. K. \& Go, S. J. (2003). Pseudomonas koreensis sp. nov., Pseudomonas umsongensis sp. nov. and Pseudomonas jinjuensis sp. nov., novel species from farm soils in Korea. Int J Syst Evol Microbiol 53, 21-27.

Laguerre, G., Nour, S. M., Macheret, V., Sanjuan, J., Drouin, P. \& Amarger, N. (2001). Classification of rhizobia based on nodC and nifH gene analysis reveals a close phylogenetic relationship among Phaseolus vulgaris symbionts. Microbiology 147, 981-993.

Mesbah, M., Premachandran, U. \& Whitman, W. B. (1989). Precise measurement of the $\mathrm{G}+\mathrm{C}$ content of deoxyribonucleic acid by highperformance liquid chromatography. Int J Syst Bacteriol 39, 159-167.

Nakagawa, Y., Sakane, T. \& Yokota, A. (1996). Transfer of "Pseudomonas riboflavina" (Foster 1944), a gram-negative, motile rod with long-chain 3-hydroxy fatty acids, to Devosia riboflavina gen. nov., sp. nov., nom. rev. Int J Syst Bacteriol 46, 16-22.

Reasoner, D. J. \& Geldreich, E. E. (1985). A new medium for the enumeration and subculture of bacteria from potable water. Appl Environ Microbiol 49, 1-7.

Rivas, R., Velázquez, E., Willems, A., Vizcaíno, N., Subba-Rao, N. S., Mateos, P. F., Gillis, M., Dazzo, F. B. \& Martínez-Molina, E. (2002). A new species of Devosia that forms a unique nitrogen-fixing rootnodule symbiosis with the aquatic legume Neptunia natans (L.f.) Druce. Appl Environ Microbiol 68, 5217-5222. 
Rivas, R., Willems, A., Subba-Rao, N. S., Mateos, P. F., Dazzo, F. B., Kroppenstedt, R. M., Martínez-Molina, E., Gillis, M. \& Velázquez, E. (2003). Description of Devosia neptuniae sp. nov. that nodulates and fixes nitrogen in symbiosis with Neptunia natans, an aquatic legume from India. Syst Appl Microbiol 26, 47-53.

Saitou, N. \& Nei, M. (1987). The neighbor-joining method: a new method for reconstructing phylogenetic trees. Mol Biol Evol 4, 406-425.

Smibert, R. M. \& Krieg, N. R. (1994). Phenotypic characterization. In Methods for General and Molecular Bacteriology, pp. 607-655. Edited by P. Gerhardt, R. G. E. Murray, W. A. Wood \& N. R. Krieg. Washington, DC: American Society for Microbiology.

Stackebrandt, E. \& Goebel, B. M. (1994). Taxonomic note: a place for DNA-DNA reassociation and 16S rRNA sequence analysis in the present species definition in bacteriology. Int J Syst Bacteriol 44, 846-849.

Thompson, J. D., Higgins, D. G. \& Gibson, T. J. (1994). CLUSTAL W: improving the sensitivity of progressive multiple sequence alignment through sequence weighting, position-specific gap penalties and weight matrix choice. Nucleic Acids Res 22, 4673-4680.

Vannini, C., Rosati, G., Verni, F. \& Petroni, G. (2004). Identification of the bacterial endosymbionts of the marine ciliate Euplotes magnicirratus (Ciliophora, Hypotrichia) and proposal of 'Candidatus Devosia euplotis'. Int J Syst Evol Microbiol 54, 1151-1156.

Vanparys, B., Heylen, K., Lebbe, L. \& De Vos, P. (2005). Devosia limi sp. nov., isolated from a nitrifying inoculum. Int J Syst Evol Microbiol 55, 1997-2000. 